\title{
Management of Human Resources in Education
}

\author{
Do Thanh Tu \\ National Academy of \\ Education Management \\ Email: tudt@niem.edu.vn
}

\author{
Duong Thi Thu Huyen \\ International School \\ Vietnam National University Hanoi \\ Email: huyendtt@isvnu.vn
}

\begin{abstract}
Human resources (HR) play an important part in all aspects of an organization's operations, including educational institutions. It is necessary to be competent to manage or handle human resources in line with tasks assigned so that they can perform their functions in the institution in which they are employed. As a result, functions in human resource management must be performed optimally in order to meet the requirements of individuals and institutions. Furthermore, it is predicted that with excellent human resource management methods, the current weaknesses in Vietnam education system in terms of competitiveness can be solved.
\end{abstract}

Index Terms - human resources; education; leadership

\section{INTRODUCTION}

$\mathrm{T}$ ODAY, improvement of science and technology is growing in lockstep with the advancement of the present time. The existence of scientific and technological progress has a significant impact on daily routines, particularly if there is no filter as a result of the development of science and technology, which will leave impact on individuals, including education. HR have a significant role in educational implementing operation. Education which is always a procedure, cannot be isolated from the function of human resources since HR are one of the most significant parts.

Furthermore, it is true to appreciate the value of human in organizational actions, because humans can occasionally become planners, agents, and drivers of organizational goal attainment. Even if the company's technologies are advanced, goals cannot be achieved without the active participation of employees. This is also true in the field of education, because the role of instructors in the learning process cannot be substituted by technology. Good management is expected to monitor HR run properly from the initial step till the final one in this field.

It is natural to discuss the existence of human resources (HR) in educational institutions since human resources (HR) play a significant administrative and operational role in the educational process. Human resources (HR) must be under proper control in order for them to fulfill their tasks. As a result, human resource management is essential (HR).

According to [18], "management is a district process consisting of planning, organizing, actuating, and controlling, performed to determine and accomplish stated objectives by the use of human beings and other resources". It is a development specific containing of a series of steps carried out to determine and accomplish given goals by the use of human / people and other resources.

Management, according to [12], is the art of getting things done via using labor force. In this sense, the responsibility of leaders is managing and directing people in order to achieve organizational goals. Management is noted as the act of operating the work of organizational members, as well as the utilization of all organizational assets, in order to meet the objectives supposedly.

Management, according to [17], is an endeavor to attain a certain objective via the activity of others. As a result, the manager manages a variety of other people's actions such as planning, organization, placement and operation. Furthermore, [1] contends that management is generally associated with each organization's activities of multiple stages from drafting to wrapping and finalizing in order to coordinate the various resources owned by the company in order to produce an efficient product or service.

It is suggested that by maximizing all available resources to conduct educational practices to achieve projected goals, it is truly the success of managing education [21]. [19] defines education management as a method for managing and structuring educational resources such as teaching staff, students, communities, curriculum, finance, infrastructure and amenities and educational context".

Thus, there are two categories distinguished in education management, namely:

(a) "Administrative management" which is concerned with actions such as planning, organization, guidance, direction, coordination, and oversight, as well as communication.

(b) "Operational management", which focuses on administration, personnel, finance, and community interactions.

"Educational management" is a method of delivering massive operations in the area of education to attain excellent educational goals [6]. From the various statements above, it is possible to conclude that education management is utilizing all educational resources in order to carry out systematic and systemic cooperation procedures which may result in efficient education implementation in order to achieve the outlined outcomes [4].

\section{Literature Review}

\section{A. Human Resource Management (HRM)}

Human beings are one of the company's or organization's resources, yet many current management policies in place do not recognize the significance of the function of $\mathrm{HR}$, therefore based on this knowledge, I can conclude that the current policy still does not prioritize human resource interests. Human resource management is an essential component of the educational process in general.

As a result, functions in human resource management must be properly carried out so as to meet the demands of individuals, organizations, and institutions. Furthermore, it 
is predicted that with excellent human resource management methods, the limitations and issues that the Indonesian people confront in terms of competitiveness would be solved. Here are some professional opinions on the idea of staff management:

(a) According to [11], personnel management is "the process of manipulating the procurement of labor, development, compensation, integration, maintenance, and termination of employment with the goal of achieving the objectives of individuals, organizations, and the community in the harmony of work.

(b). Besides, personnel administration is defined as the placement of employees inside an organization or institution. Human labor implementation entails "the acquisition, upkeep and allocation of HR" [1].

Personnel management is otherwise described as the process of "establishing, implementing, and assessing policies, procedures, techniques, and programs pertaining to individual in a work place" [16]. According to [5], personnel management is the field of management concerned with "the planning, organizing, and controlling of various functions of procurement, development, maintenance, and utilization of labor" so that (1) the association's mission is defined and carried out efficiently and successfully, (2) all employees' objectives are met to the best of their abilities., and (3) "the goals of the community are taken care of and served well".

HRM is described as the effort and procedure of developing, motivating, and evaluating the entire human resources required by the firm to achieve its goals. This comprehension comprises the following: beginning to select qualified candidates as well as how to make these sets of skills and knowledge more progressed over time [5]. Because HRM is a continuous process, similar to the educational process, it might have a specific position in educational establishments.

The HM department, or popularly known as the personnel portion, is accountable and functional as managing human resource affairs in the organizational structure of the corporation (as compared to educational institutions), thus from that knowledge it can be analyzed that HRM is a process which must create, motivate, and assess the total human resource in order for a corporation to meet its targets or objectives.

Human resources, in a broader sense, refer to the following:

a. Individuals who operate in a business setting (often referred to as personnel, labor, or employees)

b. Human potential which is an organization's activator in attaining its existence.

c. Assets and functions in the organization that are similar to capital (non-material / non-financial), and are realized as physical and non-physical potential in accomplishing the company's existence.

It is also suggested that HR development is an endeavor to improve the quality or capability of human resources via the planning, education, training, and management process of persons or workers to obtain the best possible outcome.

The personnel department's primary role is to plan the idea of human resource expansion and improvement for the organization. The major tasks of this staff include policies pertaining to labor rules, recruiting qualifications, and devel- opment ranging from sending workers to participate in continuing education, incentive programs, or labor bonuses. So, based on this understanding, it can be concluded that management is a procedure for improving an institution that involves qualifications, estimations, and developers for the process of activities such as managing, managing, and planning in order to support the achievement of goals that have been set by employing current resources.

Furthermore, HRM is a component of management. As a result, generic management theories serve as the foundation for the debate. Human resource management (HR) is primarily concerned with managing the function of individuals in achieving optimal results. This regulation addresses the issues of planning, organizing, directing, regulating, purchasing, developing, paying, integrating, sustaining, punishing, and terminating workers in order to enable the organization, employees, and the community achieve their goals.

In order to aid in goal fulfillment, HRM responsibilities include planning, organizing, mobilizing, regulating, acquiring, developing, compensating, integrating, sustaining, punishing, and

terminating corporate demands.

(a) Organizing is the action of organizing all personnel in order to achieve goals by setting the workforce division and relations.

(b) Guiding is the action of directing all employees so that they wish to work together and effectively and efficiently in order to help the firm, employees, and community accomplish their goals.

(c) Control is the action of supervising all personnel to ensure that they follow corporate policies and work as planned.

(d) Procurement is the process of obtaining workers in accordance with the firm's demands, through withdrawal, selection, placement, orientation, and induction.

(e) Development refers to the process of enhancing employees' technical, conceptual, and moral abilities via education and training. This must be relevant to current and future work requirements.

(f) Compensation is the provision of direct and indirect services, money, or products to employees in exchange for their contributions to the company.

(g) Integration is an activity that brings together the company's interests and the demands of its personnel in order to achieve collaboration that is both joyful and mutually beneficial.

(h) Maintenance refers to the performance of maintaining or developing the physical, mental, and loyalty of workers in order for them to keep working together until they retire.

(i) Discipline is the most essential function of HRM and the key to goal achievement since it is impossible to get maximum results without adequate discipline. The termination of an employee's employment connection with a corporation is referred to as dismissal (separation).

\section{B. HR Management's extension}

HRM is a subset of management. As a result, the debate is founded on broad management ideas. Human resource management (HRM) is a more concentrated debate concerning the control of individuals' roles in achieving goals. Planning, 
organizing, directing, regulating, acquiring, developing, paying, integrating, sustaining, disciplining, and terminating personnel are all covered by this legislation in order to enable the organization/institution, employees, and community achieve their goals.

The scope of HRM comprises employee scheduling which is the process of determining employee requirements, both numerically and qualitatively, for the present and future. A good and accurate personnel strategy necessitates thorough and unambiguous information on the job or activities that must be completed in the business. As a result, prior to constructing a strategy, job analysis is performed to acquire a job description.

This data is extremely useful in establishing the number of personnel required as well as in creating job criteria. This position definition offers an overview of the minimal quality of personnel that may be accepted and who must do the task as it should be done. It is possible to infer that the HR planning process is a method for setting objectives and implementing rules, and it serves as the foundation for controlling employees.

\section{Discussion}

\section{A. What Is the Goal of HR Planning?}

Some of the goals of HR planning are as follows:

(a) determining the quality and quantity of personnel who will occupy all jobs in the business.

(b) To ensure labor supply, both now and in the future, so that there is someone to do every work.

(c) To avoid mismanagement and overlap in task implementation.

(d) Increasing work productivity by facilitating collaboration, integration, and synchronization.

(e) Avoiding or overburdening personnel

It is as a framework for creating a program for employee withdrawal, selection, growth, remuneration, integration, maintenance, discipline, and dismissal.

\section{B. Procedure for Human Resource Planning}

Some examples of human resource planning techniques are as follows: (a) Clearly specify the requirements of human resources. (b) Gathering HR data. (c) Sorting and evaluating data. (c) Create a number of alternatives. (e) Construct a strategy based on the best of the available possibilities. (f) Inform personnel about the upcoming strategy. With the specified methods, it is believed that unnecessary mistakes would be avoided throughout the process of human resource planning.

\section{Employee Recruiting}

The hiring of employees is a task that aims to address the demands of an institution's employees in terms of both quantity and quality. Recruitment operations are carried out in order to discover and hire as many prospective workers who fulfill the requirements as possible, with the best and most qualified individuals being chosen. Selection is required for this purpose, which will be accomplished through oral, written, and practical exams.

However, in rare cases, personnel might be recruited internally or from inside a company whether by promotion or by transfer. If the formation is a little vacant, this is done. Other locations, on the other hand, have additional workers or are already prepared. Employee selection should be based on new principles which means we must first select the occupations based on descriptions.

This simply means that we are looking for the suitable candidates to fill the position based on job requirements. Prospective employee recruitment should be done correctly so that personnel are accepted in agreement with the requirements of the task to be done.

The following are the procedures or processes involved in the hiring of employees:

(a) Predicting workforce requirements is designed to ensure that the current and future workforce needs are met in line with the workload, that vacancies are avoided, and that all work is completed.

(b) Recruitment is the process of locating and securing people from a variety of sources in accordance with an organization's or institution's minimum requirements.

(c) The first effort that organizations / institutions must do in order to obtain suitable and competent people who will accomplish the tasks in the organization / institution is selection. The selection process must be honestly, meticulously, and objectively enacted so that the workers who are chosen are actually qualified to occupy positions and carry out the task, making it simpler to teach, develop, and manage personnel.

(d) Placement, orientation, and induction of new employees is a step after selection that involves placing potential workers who have been accepted (passed the selection) in positions / tasks that demand it while also delegating responsibility to that individual.

One of the keys to achieving the optimum job performance from every employee is proper employee placement. Workplace morale will improve, as will innovation and initiative. Each new employee must be orientated or introduced in order to demonstrate that they are actually recognized as workers who will collaborate with other employees in the business. With orientation, new workers may feel less concern and gain confidence in their job. Employee induction is a process that helps new workers acclimate to the regulations of the business or institution.

Induction is primarily the responsibility of the employee's immediate supervisor to ensure that the new employee understands the importance of following the rules of the organization/institution and doing his tasks appropriately. It may be stated that personnel procurement entails the processes of multiple stages in order to obtain effective and efficient people to assist the business / institution realize its goals.

\section{Employee Growth and Development}

The organization always expects its employees to carry out their jobs properly, give all of their talents to the organization's interests, and get better with each passing day. Aside from that, the managers need development and advancement in all aspects of his life, including his job. In this sense, the role of developing and developing workers is a function of personnel management that is critically important in order to enhance employee productivity. 
This action of coaching is concerned not only with the employee's abilities, but also with his or her career. Employee development is becoming increasingly vital as a consequence of the demands of job or position, as a result of technical improvements and increasingly severe competition among comparable businesses / institutions. Each organization's or institution's staff must be able to operate effectively with the highest quality so that the organization's or institution's competitiveness is enhanced.

This development is carried in the manner of multiple aims for employees through workshop and seminars. It can be summarized that employee development should be carried out by each organization because it will benefit the organization, working staff, and the community.

\section{E. Promotion and Mutation}

Promotion is a step that enhances an employee's power and duty to a higher position in a company, resulting in increased duties, rights, prestige, and pay. Promotion implies that there is faith and acknowledgment in the skill and capacity of the individual in question to hold a better position. Employees will be encouraged to work hard, be well disciplined, and complete tasks in order for the organization's goals to be met to the best of their abilities. Employee mutation is one of the follow-up measures conducted as a result of the outcomes of employee performance evaluation.

Since the employee performance review will inform employee abilities in performing work descriptions assigned to him, this modification must lean on the accomplishment index that the relevant employee can attain. It is reasonable to assume that mutations are part of the employee development function because the goal is to increase organizational work efficiency.

Following the acquisition and acceptance of the potential employee, the upcoming step is to make the potential employee a genuine staff of the organization, so that he has rights and duties as a member of the organization. Promotions or initial appointments for public employees in Vietnam are often appointed as interns with a trial period of one or two years, then attend training, and are appointed full time workers following graduation. Once hiring, the next step is to position or allocate staff.

\section{F. Employee dismissal}

Termination of an employee's employment with an organization should follow sequences. Dismissal signifies the end of an employee's work relationship with the company. This dismissal is a personnel function that releases organizations and individuals from their responsibilities and benegits as a workplace institution and as employees. The grounds for terminating education workers in schools, particularly Civil Servants, can be classified into three categories:

(a) Termination on one's own initiative.

(b) Disciplinary action taken by the department and the government;

(c) Suspension of the causes.

Dismissal at the employee's request, for instance, owing to a change in employment aimed at improving the employee's jobs. The department or government can fire staffs for any of the following reasons: (a) The worker in question is inept and unable to perform his job correctly.

(b) Simplifying or streamlining the organization.

(c) Rejuvenation, typically, workers over the age of 55 who are eligible to retire will go within a year.

(d) Unhealthy in both a spiritual and bodily level, preventing them from carrying out their tasks correctly.

(e) Committing a crime that results in a jail or confinement term.

(f) Violation of a government servant's commitment.

\section{G. Compensation}

Compensation is a monetary reward paid by an organization to its personnel that is often granted on a permanent basis. Other than pay, compensation can be provided in the form of perks, housing, automobiles, and other items. This compensation is no longer viewed as a means of meeting material necessities, but rather as a means of preserving human dignity.

\section{H. Employee Evaluation}

To determine if personnel who have been trained and developed profit from what they have contributed, their accomplishments must be evaluated. Work performance is the outcomes of an employee's quality and quantity of work in carrying out their duties in line with the obligations assigned to him. Individual success and engagement in school activities are used to evaluate educational staff.

Employees may utilize evaluation to get feedback on topics like ability, weariness, lack, and potential, which can then be used to set objectives, pathways, plans, and advance their careers. The findings of education staff performance appraisals are particularly significant for schools in identifying school program needs, acceptance, selection, introduction, placement, promotion, incentive systems, and other components of the entire successful human resources process are all decisions that must be made.

It may be inferred that employee evaluation is required to determine the accomplishments that each individual is capable of achieving. Organizations can utilize the evaluation results to determine future policy actions.

Schools should implement programs with the following requirements in terms of management in the realm of educators and education personnel: (1) Educational empowerment programs and personnel are organized by schools. (2) Educator empowerment and education: developed in accordance with the conditions of the school, including task distribution, overcoming manpower shortages, determining the reward system, and professional development for each educator and education staff.

\section{Conclusion}

"Human resources" play a significant role in all facets of "an institution's or organization's operations" [1]. It may work optimally if they are effectively managed. As a result, leadership is required. This management is an extremely significant part of the educational process in general. Therefore, responsibilities in human resource management must be carried out in order to meet the demands of individuals, corporations, organizations, or institutions. 
HR is a procedure that involves the execution of management duties or human resource management that is offered to the school education unit to be created in accordance with the capacity of the school. "(1) Employee planning, (2) employee procurement, (3) employee growth and development, (4) promotion and transfer, (5) employee dismissal, (6) remuneration, and (7) employee assessment are all part of the scope of human resource management (HR)" [1].

All of that must be done effectively and appropriately in order to reach the desired result, which is the availability of education employees with the necessary skills and abilities to carry out good and quality work.

\section{REFERENCES}

[1] Andrew F. Sikula, John Francis McKenna (1990) Personnel and Human Resource Management, R.E. Krieger Publishing Company

[2] Amirullah and HarisBudiyono (2004) Introduction to Management. Malang: Science Graha.

[3] AzharArsyad. (2002) Fundamentals of Management, (Yogyakarta: Student Library.

[4] Ara Hidayat and Imam Machali. (2010). Educational Management: Concepts, Principles and Applications in Managing Schools and Madrasas

[5] Awarmayanti (2013) Human Resource Management. Bandung: RefikaAditama

[6] DadangSuhardan. (2011). Et al, Educational Management, (Bandung: Alfabeta)

[7] DjonyHerfan. (1999). The Role of HR in Implementation, (Jakarta: Pt Grasindo)

[8] Ernie Trisnawati. (2005). Introduction to Management, (Jakarta: Kencana)

[9] E. Mulyasa. (2012). School Based Management. Bandung: Teen Rosdakarya.
[10] FitriOviyanti, et al. (2011). School Based Management (SBM), (Palembang)

[11] Flippo, E. B. (1961). Principles of personnel management. New York: McGraw-Hill.

[12] Follett, M. P., \& Graham, P. (1995). Mary Parker Follett--prophet of management: A celebration of writings from the 1920s. Boston, Mass: Harvard Business School Press

[13] Hasibuan, Malayu S.P. (2013). Human Resource Management.Jakarta: Earth Literacy.

[14] Herfan, Djony. (1999). Role of HR in Implementation. Jakarta: PT Grasindo.

[15] Husaini Usman. (2011). Management Theory, Practice, and Educational Research, (Jakarta: Earth Literacy)

[16] John B. Miner and Mary Green Miner (1985) Personnel and Industrial Relations, $4^{\text {th }}$ edition, Macmillan, New York

[17] Koontz, H., O'Donnell, C., \& Weihrich, H. (1982). Essentials of management. New York: McGraw-Hill.

[18] Made Pidarta. (1988). Indonesian Education Management, (Jakarta: Melton Putra),

[19] Mulyasa. (2009). Implementation of Teacher and School Principal Education Unit Level Curriculum, (Jakarta: BumiAksara).

[20] Sagala, Syaiful.(2013) Understanding Educational Organizations. Bandung: CvAlfabeta

[21] Sondang. (1997). Management Audit. Jakarta: BumiAksaraSulistyorini. 2009 Management of Islamic Education. Yogyakarta: TerasSumiharti, Yati. 1997. Management. publisher: Erlangga. Teams of Educational Administration Lecturers at the Indonesian University of Education, Education Management, (Bandung: Alfabeta).

[22] Sulasmi, E. (2020). The Development Strategy of Human Resources Management In Children's Social Welfare Institution (LKSA) (Case Study in LKSA AL-Mubaraak Orphanage Bengkulu). Budapest International Research and Critics Institute-Journal (BIRCI-Journal). P. 562-569.

[23] Wisdom. (2011). Management of Education. Bandung: A loyal library of Kadarisman. 2013. Management of Human Resource Development. Jakarta: 